IRA-International Journal of Education \& Multidisciplinary Studies ISSN 2455-2526; Vol.05, Issue 02 (2016)

Pg. no. 133-139

Institute of Research Advances

http://research-advances.org/index.php/IJEMS

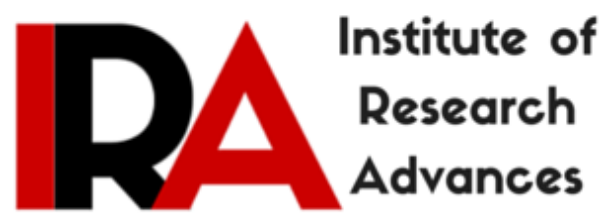

\title{
Learning problems in History subject among the Secondary School-Students of Papum-pare district of Arunachal Pradesh
}

Dr. B. Reena Tok

Associate Professor

Department of Education

Rajiv Gandhi University, Arunachal Pradesh, India.

Type of Review: Peer Reviewed.

DOI: http://dx.doi.org/10.21013/jems.v5.n2.p9

\section{How to cite this paper:}

Tok, B. (2016). Learning problems in History subject among the Secondary SchoolStudents of Papum-pare district of Arunachal Pradesh. IRA International Journal of Education and Multidisciplinary Studies (ISSN 2455-2526), 5(2), 133-139. doi:http://dx.doi.org/10.21013/jems.v5.n2.p9

(C) Institute of Research Advances

\section{(c) EY-NC}

This work is licensed under a Creative Commons Attribution-Non Commercial 4.0 International License subject to proper citation to the publication source of the work.

Disclaimer: The scholarly papers as reviewed and published by the Institute of Research Advances (IRA) are the views and opinions of their respective authors and are not the views or opinions of the IRA. The IRA disclaims of any harm or loss caused due to the published content to any party. 


\section{ABSTRACT}

This study focused to find out the learning problems of the students in the subjects of history. The study is not a fault finding assessment, rather it is an attempt to find out the problems of the students in understanding the subject, to identify the weaknesses in learning history and to suggest ways and means in alleviating the difficulties to the students. For this purpose normative survey method of research was employed. The sample consists of 100 students from government school and private secondary school of Papum-pare district of Arunachal Pradesh. The study indicates that government school students face more difficulty in learning history on regarding lengthy syllabus and content, conventional method of teaching, irregular used of teaching-learning materials, less interaction and feedback after the examination. This study thus assumes significance as it will help the teacher to have bird's eye view on the whole learning situation of the subjects.

Keywords: Learning problems, History subjects, Syllabus, Conventional method, Teaching-learning materials, Examination, Learning situation, Secondary School Students.

\section{INTRODUCTION}

Education competence in the present world is interwoven with the progress of every society. Educationists have sensitized people in comprehending that education serves as knowledge inputs, for the individual to use his potentials as a vital resource, in the direction of progress to meet the demands of the society. Learning in a classroom depends a great deal on the structure and pattern of inter-personal relationship particularly pupil-pupil relationship, existing at a given point of time within the learning group. Nowadays, much research has been carried out in "learning difficulties" (Qian, 1996). However, most of the research focused on discussion of psychology of learning, which lacks a connection to concrete content in history. Although some scholars mentioned that learning difficulty is a significant topic in the research field ( $\mathrm{Du}, 2003$; Tao, 2004), it is still rare in research that focuses on secondary school students' learning difficulties in history. In particular, there lack effective strategies to improve struggling students in their history learning processes. Learning also occupies an important place in the school. Without learning all efforts of pupils as well as of teachers are bound to become purposeless. Learning essentially consists in the modification of reaction due to experience or practice. Every stimulation produces some changing reaction due to experiences. Learning is a key process and continuous process in human behavior. Learning includes not only the outward behavior of the person but it also includes the other process as effective observations, memorization, understanding ideas and relationship, emotional control and skills. More, Manning and Smith (1978) "Learning is limited to those changes in behavior which are result of training or experience and not a result of maturation or temporary physiological or psychological states of the organism". 'History' in academic study of the past or the product of our attempts to understand the past, we also look at important figures, important events, important groups, ideas and movements. According to E.H Carr "History is a continuous process of interaction between the historian and his facts, and unending dialogue between the present and the past". History is so broad that it can include everything from what has happened in India, Latin America, China and Europe and all over the world. History is also one of the most important subjects in the secondary level of schools. The subject's history and its learning promoted national integration, feeling of nationalism and integrity of India. History inspires the students' love of motherland place in education especially among the school students in the country. Learning about history is important because some of it should be common knowledge. By knowing a bit about what has happened in our world, we can help see why things are the way they are as of now, what will happen in the future, how great minds work, how evil people work and how much more. One basic importance of history is to know enough to do well because our knowledge of it is tested. If we do not know enough, than we put our self at risk of not 
achieving what we can. If we do not know about what has happened, we do not truly understand the world.

But students in the government school and private school in Papum-pare district of Arunachal Pradesh, they are facing a lot of problem in understanding the subjects, as this subject is very vast, the teacher are mostly untrained and they are not able to arouse interest among students while teaching the students. The majority of the students come from a low socio economic family so they cannot afford to buy good books related to history subject and students also lack proper understanding and communicating in languages for examples in some school they use mother tongue languages as a medium of instruction. Mostly students express that the subject is boring for them as a result their problem of learning the subject gets aggravated. Whereas learning the subject and passing the subject is essential to get promoted to higher class. Therefore learning of history is important to the student; the teacher has to play a very important role in motivating the students to develop interest towards history subject. Therefore investigators decided to study the learning problem in history. This study will identify the learning difficulties related to history and suitable approach will be followed to make teaching of history effective and meaningful.

Mudliar commission (1952-1953) recommended social studies to be taught to every secondary school public. The international team recommended that social studies should be compulsory for all and to spread over three or four years. The seminar on educational administration held at Srinagar in 1956 also recommended that social studies should be studies even up to the end of higher secondary stage.

Morrissett (1982) he suggested that the following points characteristic the present and future status of social studies education;

- A renewal of interest at variety of teaching methods and materials.

- A growing interest in social concern and controversial.

- A revolution in the content, methodology and organization of the social studies base on the commuter.

Gambell (1987) emphasized the need for developing of student communication skills which include speaking, reading, writing, listening, viewing and other non- verbal communication. The social studies classroom is an ideal environment for facilitation the development of all the skills.

Dhand Harry (1990) found that 43 percent of the titles reviewed were found to pose some define problem, errors of facts of attribution at all grade level were detected in adequate treatment and development of contextual information existed in the textbook could lead misinterpretation, the educational establishment at all level, including curriculum developers publishers and writer, often did not know their subject- matter well enough to convey its without and variety of errors.

Hermann kulke and Dietmar Rothermund (2004) remarked that a history of India presents the grand sweep of Indian history from antiquity the present in a compact and readable survey. The authors examine the major political, economic, social and cultural forces which have shaped the history of the Indian subcontinent. Providing an authoritative and detailed account.

Jorn Rusen (2006) without denying the importance of the postmodernist approach to the narrative form and rhetorical strategies of historiography, the author, one of Germany's most prominent cultural historians, argues here in favor of reason and methodical rationality in history. He presents a broad variety of aspects, factors and developments of historical thinking from the $18^{\text {th }}$ century to the present, thus continuing, in exemplary fashion, the tradition of critical self-reflection in the humanities and looking at historical studies as an important factor of cultural orientation in practical life. 
In view of the review of related literature it has been observed that the history is necessary for a good general education. It makes students aware about the past, its mistakes, how that happened and its consequence and learns how war is not good for human development. The main emphasis for inclusion of history at secondary stage is to help the student to acquire knowledge of their environment and develop certain attitudes for intelligent participation in the affair of the community, the state, the nation and the world at large. At the national level the place of history is for the development of ideal citizenship and values for secular socialist society and emotional integration.

\section{OBJECTIVES OF THE STUDY}

1. To find out the problem in history subject of secondary students of Government schools and Private schools of Papum-pare district of Arunachal Pradesh.

2. To suggest measures to solve the difficulties found by students in learning of history.

\section{METHODOLOGY}

The present study was conducted to study the learning problems in history subject among the secondary school students of Papum-pare district of Arunachal Pradesh. For this purpose, normative survey method of research was employed in the present investigation.

Sample: The sample was collected using the random sampling technique. It comprised of 100 secondary school students of Papum-pare district of Arunachal Pradesh. It was divided into 50 Government school students and 50 Private school students.

Tools: For the present piece of research work in order to forge the research findings the investigator used the following tool.

1. Questionnaire on learning problems in history for students developed by Dr. Yodida Bhutia (2011)

\section{Statistical techniques used:}

Data was analyzed qualitatively and quantitatively. Percentage was calculated for analyzing the data. Each item of the responses was analyzed by giving the percentage. On the basis of the percentages for each item, data were interpreted.

\section{ANALYSIS AND INTERPRETATION}

Problems in learning history subject of secondary student from Government and Private school. The learning problem in history subject is divided into different dimension which are further classified into component and question wise. There are six identified dimension in learning problem of history subject such as syllabus, teaching, teacher, infrastructure, evaluation and Co-curricular activities. The investigators focused mainly on syllabus, teaching and the teacher dimensions for the study. 
Table No 1. Showing learning problems of students from Government and Private Secondary schools as regard to content component of History subject.

\begin{tabular}{|l|l|l|l|l|}
\hline \multirow{3}{*}{$\begin{array}{l}\text { Component } \\
\text { of syllabus }\end{array}$} & Items & Options & \multicolumn{2}{|l|}{ Percentage of response } \\
\cline { 3 - 5 } & & & $\begin{array}{l}\text { Govt. } \\
\text { schools }\end{array}$ & $\begin{array}{l}\text { Private } \\
\text { schools }\end{array}$ \\
\hline \multirow{4}{*}{ Content } & History subject & Interesting & $38 \%$ & $71 \%$ \\
\cline { 3 - 5 } & Boring & $62 \%$ & $39 \%$ \\
\cline { 2 - 5 } & $\begin{array}{l}\text { Difficulty in understanding } \\
\text { the lesson }\end{array}$ & Yes & $57 \%$ & $52 \%$ \\
\cline { 2 - 5 } & Lengthy syllabus & No & $43 \%$ & $48 \%$ \\
\cline { 2 - 5 } & & Yes & $59 \%$ & $51 \%$ \\
\cline { 3 - 5 } & No & $41 \%$ & $49 \%$ \\
\hline
\end{tabular}

\section{Interpretation:}

From the above Table NO 1. It shows that 71 percent Private school students find history subject interesting and boring percent Whereas Government schools percent interesting \& more of boring in subject with percent. It also indicates that both the Government percent and 52 percent Private school students find difficulty in understanding the lesson and find the history book lengthy. It shows that Government school students face more difficulty and boring as compared to Private school students of Papum- pare District of Arunachal Pradesh.

Table No 2. Showing learning problems of Government secondary students and Private school students as regard to completion of Syllabus.

\begin{tabular}{|c|c|c|c|c|}
\hline \multirow{2}{*}{$\begin{array}{l}\text { Component of } \\
\text { syllabus }\end{array}$} & \multirow[t]{2}{*}{ Item } & \multirow[t]{2}{*}{ Options } & \multicolumn{2}{|c|}{ Percentage of response } \\
\hline & & & Govt. schools & Private schools \\
\hline \multirow{3}{*}{$\begin{array}{l}\text { Completion } \\
\text { syllabus }\end{array}$} & \multirow{3}{*}{$\begin{array}{l}\text { Timely completion } \\
\text { of syllabus }\end{array}$} & Always & $39 \%$ & $74 \%$ \\
\hline & & Sometimes & $40 \%$ & $23 \%$ \\
\hline & & Never & $21 \%$ & $3 \%$ \\
\hline
\end{tabular}

\section{Interpretation:}

Table NO. 2. shows the timely completion of syllabus in Private schools is 74 percent always, 23 percent sometimes \& 3 percent never whereas, the Government schools shows that 39 percent always, 40 percent sometimes and never 21 percent. From the table it indicates that students from the Government schools are facing more problems during test/ examination because the teachers are unable to complete the syllabus on time. Thus, Teachers from both the management should try to complete the syllabus on time. 
Table No 3. Showing learning problems of Government secondary students and Private school students regard to methods, teaching aids and Language difficulty.

\begin{tabular}{|l|l|l|l|l|}
\hline $\begin{array}{l}\text { Component } \begin{array}{l}\text { Teaching } \\
\text { Tef }\end{array} \\
\text { Item }\end{array}$ & Option & \multicolumn{2}{|l|}{ Percentage of responses } \\
\cline { 3 - 5 } & & & Govt. schools & $\begin{array}{l}\text { Private } \\
\text { schools }\end{array}$ \\
\hline \multirow{4}{*}{ Teaching } & Methods & Lecture & $73 \%$ & $61 \%$ \\
\cline { 3 - 5 } & Discussion & $27 \%$ & $39 \%$ \\
\cline { 2 - 5 } & Teaching Aids & Always & $0 \%$ & $12 \%$ \\
\cline { 3 - 5 } & Sometimes & $17 \%$ & $20 \%$ \\
\cline { 3 - 5 } & Language & English & $18 \%$ & $73 \%$ \\
\cline { 3 - 5 } & Hindi & $82 \%$ & $27 \%$ \\
\hline
\end{tabular}

\section{Interpretation:}

From the above Table No 3. It shows that 73 percent, 61 percent respectively, that teacher are commonly adopting lecture method and hardly 27 percent, 39 percent from the Government and Private school teachers follow discussion method. It is discouraging to notice that both the institution only handful of teachers use Teaching aids sometimes while teaching in the classroom. The table also reveals that Government school teachers are teaching in Hindi language mostly with 82 percent and hardly 18 percent in English whereas Private school teachers found more comfortable to teach in English language. It shows that Government school students found more problems in understanding English language and to write in exams. Thus, teachers should try to make the classroom teaching more interesting by adopting different methods and use regular Teaching learning materials so that the students do not face problem in understanding the concepts clearly

\section{RESULT AND CONCLUSION}

The present study shows that 54 percent secondary students find the syllabus of the subject content lengthy due to which timely completion of syllabus is not possible. The students stated that the teachers explained in simple words and without example, the study of Gupta (1953) are related to present apathy towards teaching and learning in schools. A rigid syllabus, traditional nature of questions factors for the present day apathy towards history subject.

The present study also reveals that the teachers are not using teaching learning materials regularly while teaching and majority of the students are not satisfied with the teaching method because the history teachers use lecture method mostly and rarely give feedback after the examination which is also found by Narayanas Swami (1960) made an inquiry unto the teaching of social studies in the secondary school. Inadequate of book and other teaching material, failure to audio-visual aids in teaching and inadequate education measure were some of the defected located. Reflection is very important for the contemporary teachers. It really helps to focus on strengths and weaknesses in teaching and where improvement is needed.

On the basis of the findings of the study the investigators made some suggestions with regard to the history learning:

1. The content of the history subject should be interesting, simple\& comprehensive to the entire student. 
2. The history book should be written in easy language and should be presented in an attractive way with different pictorial presentations of history events.

3. The teacher should try to complete the syllabus in time and revise the syllabus before the exam.

4. Teacher should be well trained and must have knowledge of the subject, methods and techniques of teaching.

5. The teachers should try to encourage classroom interactions with the students while teaching.

6. All the school teachers should prepare good teaching aids and innovation teaching learning materials.

7. Teacher should give feedback to help the student to know their strength and weaknesses.

8. The school administration should organize field trips to historical places and monuments relating to their subject.

9. The teacher should continuously motivate and teach effectively.

Thus, learning occupies an important place in the school and in the student's life. It is a key process and continuous process in human behaviors. This study was made on learning problems of the students in the subject of history and not a fault finding assessment. Rather it is an attempt to understand the problems of the student in understanding the subject, to identify the weaknesses in learning history. Teaching today demands of the teacher that he or she should go about his work with skills and professionalism. This study thus assumes significance as it will help the teacher to have bird's eye view on the whole learning situation of the subject.

\section{REFERENCES:}

Buch M.B (1991) Fourth survey of research in education 1983-1988 volume-1.National council of educational research and training.

Dhand Harry (1990) Research in Teaching of the social studies publishes by- SB Nangia for Ashish publishing house. New Delhi.

Gambell (1987) Review of research in social studies education: 1976-1983. Washington D.C National council for the social studies, 1985 .

Hermann Kulke, Dietmar Rothermund (2004) A history of India. Routledge, 2004 http;//books.google.co.in

Jorn Rusen (2006) Narration, Interpretation, orientation. Berghahn books,http://books.google.co.in

Morrissett (1982) Wisconsin: paper presented to "Rethinking social education" a national conference on future direction for social studies.

Koul, L. (1997). Methodology of Educational Research. New Delhi: Vikash Publishing house.

Kyntiewlin Lyngdoh (2011). A Study of the learning problems in history among the secondary school students of Mawkyrwat block, west Khasi hills, Meghalaya.

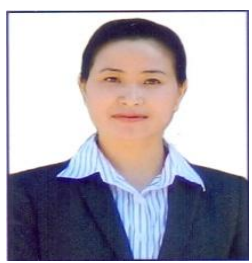

B. Reena Tok received her Ph.D degree in Education from Rajiv Gandhi University, Arunachal Pradesh, India in 2005. She is currently working as Associate Professor at the Department of Education. She is a gold medalist in Bachelor of Education in 2003. Her research interests are Creative Thinking Ability, Educational Psychology. She is a life member of NEISE, AIERA. She is the programme Coordinator in charge of MA, B.Ed and M.Ed. IGNOU Programme. 